\title{
AGAMA SEBAGAI MEDIA DAN MEDIA SEBAGAI AGAMA
}

\author{
Dwi Wahyuni \\ Program Studi Religious Studies \\ Pascasarjana UIN Sunan Gunung Djati Bandung \\ wahyunid27@gmail.com
}

\begin{abstract}
Religion can be a medium of integration as well as a medium that can lead to disintegration in the midst of society. Therefore, in this paper will examine how religious formulations should be understood as a framework of values, so the most important thing is to implement the values contained in religion itself, rather than being a narrative text or rigid formal symbols. And finally the religious presence is able to help human beings in good moral and psychological formation. On the other hand also, the presence of media in modern society, especially television and internet that so affect the actions of modern humans. This phenomenon makes the media a "new religion" of modern society. This research is done by descriptive analysis approach, to describe the phenomenon of religious entity and media, with the observation variable to specially determined things. The collected data is then analyzed and interpreted using descriptive-qualitative analysis technique.
\end{abstract}

Key words: Religion, Media, Integration and Disintegration

\begin{abstract}
Abstrak : Agama dapat menjadi suatu media integrasi sekaligus juga sebagai media yang dapat menimbulkan disintegrasi ditengah-tengah masyarakat. Karena itu, dalam tulisan ini akan mengkaji bagaimana formulasi agama sebaiknya dipahami sebagai kerangka nilai, sehingga yang terpenting ialah mengimplementasikan nilai-nilai yang dikandung agama itu sendiri, bukan menjadi narasi teks atau simbol-simbol formal yang kaku. Dan akhirnya kehadiraan agama mampu membantu manusia dalam pembentukan moral dan psikologis yang baik. Pada sisi lain juga, kehadiran media pada masyarakat modern, khususnya televisi dan internet yang begitu mempengaruhi perbuatan-perbuatan manusia modern. Fenomena ini menjadikan media sebagai "agama baru" masyarakat modern. Penelitian ini dilakukan dengan pendekatan analisis deskriptif, untuk menggambarkan fenomena entitas agama dan media, dengan variabel pengamatan kepada hal-hal yang telah ditentukan secara spesifik. Data yang terkumpul kemudian dianalisis dan diinterpretasikan dengan menggunakan teknik analisis deskriptif-kualitatif.
\end{abstract}

Kata kunci : Agama, Media, Integrasi dan Disintegrasi 


\section{A. Pendahuluan}

Dua istilah yang menjadi dasar dalam tulisan ini yaitu kata "agama dan Media". Pada umumnya setiap orang tentu telah memiliki ide dan pengertian masing-masing tentang apa yang dimaksud dengan Agama. Begitu juga dengan kata media, setiap orang telah mempunyai pengertian yang umum tentang kata ini. Namun demikian, dirasa perlu untuk membatasi pengertian kedua istilah di atas dan diharapkan arah pembahasan kedua kata (Agama dan Media) terfokus pada sebagaimana pengertian yang dimaksud dalam tulisan ini.

Istilah "Agama" semata-mata hanya digunakan dalam bahasa Indonesia dan Melayu, sedangkan dalam forum internasional dari ilmu agama-agama, digunakan istilah religio (dalam bahasa Latin) atau religion (dari bahasa Inggris) (Olaf Herbert, 2013:4). Dalam buku Islam Ditinjau Dari Berbagai Aspeknya, Harun Nasution memberikan pengertian agama yang salah satu nya ialah mengikatkan diri pada suatu bentuk hidup yang mengandung pengakuan pada suatu sumber yang berada di luar diri manusia dan yang mempengaruhi perbuatan-perbuatan manusia (Harun, 2011:2).

Sehingga dalam pengertian sederhananya, agama merupakan penghambaan manusia terhadap Tuhannya, dimana penghambaan itu mempengaruhi perbuatan-perbuatan manusia tersebut. Oleh karena itu, ada tiga unsur dalam pengertian agama, ialah manusia, Tuhan dan penghambaan. Maka suatu ajaran dan paham yang mengartikan ketiga unsur pokok pengertian tersebut dapat juga disebut sebagai agama.

Pengertian media dalam KBBI, diartikan sebagai: 1.Alat. 2.Alat atau (sarana) komunikasi seperti majalah, radio, televisi, film, poster, dan spanduk (KBBI, 2001:72). Dalam etimologinya, kata "media" berasal dari bahasa Latin "medius" yang berarti tengah. Sedangkan dalam bahasa Indonesia, kata "medium" diartikan "antara" atau "sedang”, jadi pengertian media dapat mengarah pada sesuatu yang mengantar atau meneruskan informasi (pesan) antara sumber (pemberi pesan) dan penerima pesan. (http://infodanpengertian.blogspot.co.id/2015/04/pengertian-media-menurut-paraahli.html).

Definisi media menurut Association for education and communication technologi (AECT) ialah segala bentuk yang di pergunakan untuk suatu proses penyaluran informasi. Sedangkan Definisi menurut education association (NEA), sebagai benda yang dapat dilihat, dibaca, didengar, atau dimanipulasikan, beserta instrumen yang dipergunakan dengan baik (Basyirudin Usman, 2002:12).

Dari kedua istilah agama dan media yang telah dijelaskan di awal, kedua entitas ini menjadi hal yang menarik untuk dipahami secara baik. Dalam prespektif sosiologis, agama dapat menjadi suatu media integrasi sekaligus juga sebagai media yang dapat menimbulkan disintegrasi ditengahtengah masyarakat. Karena itu, dalam tulisan ini akan mengkaji bagaimana formulasi agama 
sebaiknya dipahami sebagai kerangka nilai, sehingga yang terpenting ialah mengimplementasikan nilai-nilai yang dikandung agama itu sendiri, bukan menjadi narasi teks atau simbol-simbol formal yang kaku, akhirnya kehadiraan agama mampu membantu manusia dalam pembentukan moral dan psikologis yang baik. Pada sisi lain juga, kehadiran media pada masyarakat modern, khususnya televisi dan internet yang begitu mempengaruhi perbuatan-perbuatan manusia modern. Fenomena ini menjadikan media sebagai "agama baru" masyarakat modern.

Oleh karena itu, menarik diteliti sebagaimana dengan permasalahan-permasalahan yang telah disampaikan di awal. Penelitian ini dilakukan dengan pendekatan analisis deskriptif, untuk menggambarkan fenomena entitas agama dan media, dengan variabel pengamatan kepada hal-hal yang telah ditentukan secara spesifik. Data yang terkumpul kemudian dianalisis dan diinterpretasikan dengan menggunakan teknik analisis deskriptif-kualitatif.

\section{B. Agama Sebagai Alat Integrasi dan Disintegrasi di Tengah-Tengah Masyarakat}

Dalam masyarakat majemuk, agama dapat menjadi faktor integrasi, sebagaimana juga dapat dengan mudah disalahgunakan sebagai alat disintegrasi. Agama pada satu sisi menciptakan ikatan bersama, baik antara anggota masyarakat maupun dalam kewajiban-kewajiban sosial yang membantu mempersatukan mereka (Elizabeth,1993:42). Tetapi di sisi lain, perasaan seagama saja tidak cukup untuk menciptakan perasaan memiliki kelompok atau kesatuan sosial. Maka harus ada faktor-faktor lain yang lebih memperkuat dan mempertahankan kohensi sosial.

Perbedaan konsepsi di antara agama-agama yang ada adalah sebuah realitas, yang tidak dapat dimungkiri oleh siapa pun. Dalam prakteknya hal yang sering memicu konflik fisik dan non-fisik antara umat beragama. Adanya perbedaan bahkan benturan konsepsi yang terjadi dihampir semua aspek agama, baik bidang konsepsi tentang Tuhan maupun konsepsi pengaturan kehidupan.

Konflik Maluku, Poso, ditambah sejumlah kasus di berbagai tempat antara umat Islam dan kristen disebabkan oleh bedanya konsepsi antara kedua agama ini. Umat Islam dipandang sebagai umat yang radikal, tidak toleran, dan sangat subjektif dalam memandang kebenaran yang boleh jadi terdapat pada umat agama lain. Sedangkan umat Kristen dipandang sebagai umat yang bertendensi menguasai segala aspek kehidupan dan berupaya menyebarkan pesan Yesus yang terakhir serta sangat ambisius agresif.

Sebenarnya tidak dimungkiri bila teks keagamaan mengatur masalah perperangan dan kekerasan. Misalnya, tradisi Judeo-Christian, Yehweh digambarkan sebagai "God of War", sebagaimana diterangkan dalam Mazmur 18: 40- 41. Begitu pula dalam Islam dikenal tentang jihad yang dalam beberapa hal berarti qital (peperangan). Sehingga sebagian pengamat menilai salah satu 
sumber konflik ialah agama, yang paling tidak agama telah memberi legitimasi terhadap berbagai konflik yang terjadi. Sebagian pengamat lain juga menyatakan bahwa agama-agama memiliki ajaran dan contoh-contoh dimana ajaran dan contoh telah melegitimasi pembunuhan. Kara mereka, Dalam tradisi Islam dan Kristen bahkan Yahudi, Tuhan telah membunuh masyarakat, dan juga memerintah masyarakat untuk membunuh (Lester: 215-216).

Sudut pandang terhadap agama yang memposisiskan agama sebagai salah satu sumber konflik, menjadi motivasi dalam berbagai upaya menafsirkan kembali ajaran-ajaran agama, yang selanjutnya dicarikan titik persamaan pada level tertentu. Hal ini dilakukan dengan harapan agar konflik antara umat beragama akan teredam jika faktor "kesamaan agama" itu dikedepankan. Pada hal-hal yang bersifat eksoteris, seperti halnya aspek syari'ah, agama-agama satu sama lain memang berbeda, namun pada hal-hal yang bersifat esoteris, semua agama sama. Sehingga semua agama dipandang sama-sama sebagai jalan yang sah untuk menuju kepada Tuhan (Abdul Munir, 2002:44).

Dalam kajian sosiologis, agama dipandang mempunyai peran yang multifungsional. Elizabeth K. Nottingham, menyebut paling sedikit tiga fungsi agama, yaitu: pemeliharaan ketertiban masyarakat, fungsi integratif dan fungsi pengukuhan nilai (Elizabeth, 1988:97). Dengan fungsifungsi tersebut, agama seperti dikatakan Clifford Geertz, memunculkan dirinya sebagai kekuatan integrasi social (Clifford, 1960:57) Demikian juga sebagaimana yang pernah dinyatakan Sunaryo Adhiwardoyo dimana Durkheim memandang bahwa agama sebagai faktor integrasi masyarakat dan merupakan faktor yang penting juga bagi identitas. Lain halnya dengan Karl Marx yang memandang bahwa agama merupakan bagian dari superstruktur kelas penguasa agar dapat mereproduksi "kesabaran sosial" atau kecanduan dunia (reification) bagi melaratnya nasib kehidupan kelas bawah sehingga kelas bawah ini tetap setia secara identitas dan integrasi sosialnya pada pimpinan-pimpinan kelas penguasa (Sunaryo, 2005:75).

Meskipun demikian, kehadiran agama selalu disertai dengan "dua muka". Di satu sisi yang secara inheren, agama telah memiliki identitas yang bersifat primordial eksklusif, dan partikular. Dan pada sisi lain juga, agama kaya akan identitas-identitas yang bersifat transedental, inklusif, dan universal (Jose Casanova, 1994:4). Paling tidak ada dua hal yang mestinya dilihat dari penjelasan ini, yang pertama ialah memahami posisi agama serta meletakkan agama tersebut dalam situasi yang benar-benar riil agama secara empirik dan dihubungkan juga dengan berbagai persoalan-persoalan sosial kemasyarakatan. Dan dalam konteks yang kedua, sering ditemukan ketegangan-ketegangan antara kedua wilayah tersebut yakni agama dan persoalan kemasyarakatan.

Potensi-potensi antagonistik inilah yang menjadi salah satu perhatian penting para pemikir agama dan aktivis selama ini. Dimana antagonisme yang berkembang pada lingkungan agama ini 
terjadi pada dua tingkatan, yang pertama yaitu ketegangan atau konflik yang berkembang di kalangan umat suatu agama, yang kedua ketegangan atau konflik yang terjadi antar umat yang berlainan agama. Akar dari antagonisme ini bersumber dari lingkupan teologis berbeda sudut pandang dalam mencoba memahami norma-norma agama, seperti halnya memahami agama mempunyai identitas yang bersifat primordial, eksklusif, dan partikular (Bahtiar, 2001:24).

Dengan demikian, tampilnya sekian banyak agama dan aliran kepercayaan akan berkonsekuensi munculnya ketegangan dan konflik antar umat beragama. Kalangan singularistik beragumen bahwa setiap agama mengajarkan bahwa doktrinnyalah yang unik, eksklusif, superior dan yang paling benar dibanding agama yang lain. Pandangan keagamaan yang demikian selalu mengarah pada sikap keagamaan yang eksklusif, yang seringkali menjadi persoalan sosial yang dapat mengganggu integritas masyarakat. Fenomena ini dipahami sebagai salah satu faktor yang dapat menimbulkan konflik-konflik sosial, baik karena bertolak dari suatu kepentingan keagamaan yang sempit, maupun bertolak dari supremasi budaya kelompok masyarakat tertentu.

Oleh karena itu, yang terpenting ialah sikap keberagamaan yang terbuka (inklusif) sangat berperan dalam menghadirkan wajah agama yang berfungsi integratif. Merupakan hal yang sangat penting dan menyangkut dimensi yang sangat luas untuk mewujudkan kerukunan umat beragama. Oleh karenanya menciptakan kerukunan umat beragama perlu partisipasi dari berbagai pihak, khususnya pemerintah dan masyarakat, serta menuntut penanganan yang komprehensif, termasuk bidang-bidang yang sering disebut sebagai variabel sosial keagamaan, seperti ekonomi, sosial, budaya, politik dan hukum yang mewarnai pola perilaku masyarakat dan umat beragama. Dan juga terpenting ialah Mengimplementasikan esensi nilai-nilai ajaran agama dalam kehidupan publik jauh lebih penting daripada sekedar terjebak pada simbol-simbol formal, yang rentan terpeleset menjadi sekadar komoditas politik (Agus Ahmad, 2016).

Lebih jauh lagi, hubungan antar umat beragama yang menjadikan wajah agama sebagai integrasi masyarakat, diharapkan pada kerja sama yang nyata dalam kehidupan sehari-hari, semua agama beragenda sama untuk melawan musuh bersama, musuh dari kemanusiaan yaitu ketidakadilan sosial, kemiskinan, kebodohan, pelanggaran hak asasi manusia dan kepatuhan kepada tirani yang jauh dari kesadaran akan Ketuhanan Yang Maha Esa. Semua agama punya tanggung jawab terhadap kerja nyata ini supaya dapat terwujud secara maksimal (Dwi Wahyuni, 2016).

\section{Media Sebagai Agama Baru Masyarakat Modern}

Perkembangan dan pertumbuhan teknologi informasi komunikasi sekarang ini telah merubah cara interaksi antara individu satu dengan individu lainnya. Misalkan dengan adanya internet yang 
menjadi sebuah ruang digital baru, dimana internet ini telah menciptakan sebuah ruang kultural yang berbeda dari sebelum ada dan menyamurnya internet (Pardianto, 2013). Tidak dapat dihindari bahwa keberadaan internet memberikan banyak kemudahan kepada penggunanya. Dengan adanya internet akses-akses terhadap informasi dan hiburan dari berbagai penjuru-penjuru dunia dapat dicari dengan singkat dan mudah. Internet telah menembus batasan dimensi kehidupan para penggunanya, dengan waktu, dan ruang, internet dapat diakses dimanapun, kapanpun dan oleh siapapun (Khairuni, 2016).

Dengan adanya internet secara tidak langsung telah menghasilkan suatu generasi baru, yaitu generasi yang disebut dengan generasi $n e(x t)$. Generasi ini merupakan generasi yang dipandang menjadi sebuah generasi masa depan dengan diasuh dan dibesarkan dalam lingkupan kultur baru media digital yang berwatak menyendiri, yang interaktif berkomunikasi secara personal, dibesarkan dengan videogames, melek komputer, dan lebih banyak waktu luang untuk menonton televisi dan mendengarkan radio (Idi Subandy, 2011:310).

Sekarang ini tanpa disadari telah terjadi pergeseran tradisi budaya, dari kebiasaan menggunakan media tradisional yang tergantikan dengan menjadi budaya media digital. Misalkan Facebook yang merupakan Salah satu media sosial yang pengaruhnya sangat dominan pada masyarakat Indonesia. Koran Kompas Pada tahun 2009 menyatakan bahwa pengguna Facebook di Indonesia mencapai 11 juta orang. Keberadaan media sosial telah mengubah bagaimana akses terhadap teknologi digital berjaringan (Primada, 2015).

Penggunaan terhadap media sosial pada budaya media digital saat ini merupakan sesuatu yang sulit untuk dapat dihindari lagi. Setiap hari masyarakat modern mengakses media sosial dan ini dilakukan hanya untuk sekedar mencari informasi-informasi melalui Google dan Facebook. Dan ada juga menggunakan media sosial dengan menyampaikan aktivitas-aktivitas yang mereka lakukan melalui twitter atau path. Kementrian Kominfo dalam hasil surveynya menunjukkan ada 5 media sosial yang terpopuler di negara Indonesia, yaitu Path 700 juta pengguna, Facebook dengan 65 juta pengguna, Twitter 19,5 juta pengguna, Google kurang lebih 3,4 juta pengguna, dan LinkedIn 1 juta pengguna (Suara Merdeka, 2015).

APJII berkerja sama dengan Lembaga Polling Indonesia, melakukan survey yang menghasilkan dalam datanya lebih dari setengah penduduk Indonesia sekarang ini telah terhubung ke internet. Pada tahun 2016 tercatat sekitar 132,7 juta penduduk Indonesia telah terhubung ke internet dari total keseluruhan penduduk Indonesia sebanyak 256,2 juta orang. Pada tahun 2016 ini mengalami peningkatan yang mencapai 51,8\% dibandingkan dari tahun 2014. Dimana pada 2014 tercatat hanya 88 juta penduduk Indonesia sebagai pengguna internet. Kenaikan ini disebabkan oleh perkembangan infrastruktur dan mudahnya mendapatkan smartphone atau perangkat genggam 
(http://tekno.kompas.com/read/2016/10/24/15064727/2016.pengguna.internet.di.indonesia.capai.132. juta).

Meski demikian, pengguna internet sebagaimana diterangkan di atas, mayoritas penggunanya merupaka masih berada di Pulau Jawa. Dalam hasil survei yang disampaikan oleh APJII tercatat bahwa kurang lebih sekitar 86,3 juta orang atau sekitar 65 persen dari pengguna internet pada tahun 2016 ialah berada di Pulau Jawa. Lebih jauh hasil survie ialah sebagai berikut, 2,5 persen atau 3,3 juta di Maluku dan Papua, 4,7 persen atau 6,1 juta di Bali dan NTB, 5,8 persen atau 7,6 juta di Kalimantan, 6,3 persen atau 8,4 juta di Sulawesi, 15,7 persen atau 20,7 juta di Sumatera.

Dari data-data sebagaimana yang di terangkan di atas dapat menunjukan betapa mendominannya media terhadap masyarakat modern saat ini. Tidak hanya pada masyarakat perkotaan namun sudah sampai pada masyarakat perdesaaan. Fenomena pada masyarakat modern sekarang ini, media merupakan kebutuhan yang penting untuk mendapatkan informasi dari dunia luar maupun hanya sekedar hiburan. Karena masyarakat kita sudah banyak belajar dari media. Segala kebutuhan sehari-hari, gaya hidup dan tingkah laku sudah disesuaikan dengan apa yang terjadi pada media yang mereka akses. Realitas yang sudah menggejala ini, dikhawatirkan akan memunculkan ketergantungan yang begitu besar masyarakat pada media. Ketergantungan yang besar akan menyebabkan media menjadi acuan, penuntun, nasihat bagi masyarakat. Kemudian medialah yang mengarahkan hidup masayarakat (M. Hatta, 2017).

Media merupakan sarana empuk untuk penyampaian ilmu pengetahuan. Fakta riil menunjukkan bahwa media sangat menentukan perilaku masyarakat. Apa yang disajikan oleh media cenderung diikuti oleh para penikmat media itu sendiri, tidak terkecuali dengan model atau realitas pendidikan di Indonesia. Kehadiran media telah membentuk pola pembelajaran satu arah. Ini berarti bahwa anak didik hanya melihat dengan tanpa mampu mengoreksi secara proporsional sistem nilai dan aplikasi yang ada.

Mahasiswa misalnya lebih cendrung mengakses apa yang mereka cari melalui internet ketimbang membaca buku untuk mendapatkan referensi pelajarannya. Kenyataan ini akan membuka peluang sistem belajar pasif dan satu arah. Anak didik cenderung mendengarkan apa yang ditawarkan dan dilihatnya lewat media, hal ini mengakibatkan sulitnya melatih berpikir kritis terhadap apa yang diajarkan oleh para pendidik kepada para peserata didik.

Akibat kenyataan yang berlarut-larut seperti itu yang telah menjadi fenomena kehidupan masyarakat modern dapat mengakibatkan timbulnya "agama baru" dalam masyarakat. Karena agama merupakan dasar pijakan kuat manusia yang berhubungan dengan Tuhan atau sesama manusia itu sendiri. Sejatinya agama ialah merupakan tempat berpegang manusia dalam kehidupan agar tidak 
terombang-ambing dalam ketidaktahuan. Dengan agama juga lah sejatinya manusia dituntun, diarahkan bahkan diharuskan agar melakukan segala sesuatu dan tidak melakukan sesuatu yang lain. Intinya sumber utama pengetahuan kehidupan manusia adalah agama.

Fenomena-fenomena yang ada bahwa masyarakat modern sekarang lebih mengagungkan media sebagai rujukan hidupnya karena dengan media masyarakat mudah mendapatkan apa yang mereka perlukan seperti belanja online sampai dengan angkutan umum online. Untuk kebutuhan hidupnya masyarakat dengan mudah bisa memesan bahkan memilih lewat media smartphonenya. Begitupun dengan kegiatan sehari-hari mulai dari bangun tidur hingga tidur lagi, masyarakat modern, sebagian besarnya membutuhkan akses media melalui smartphone pribadi masing-masing dan tidak sedikit yang pertama diperhatikan saat bangun tidur ialah smartphone. Bahkan sekarang peranan media telah mengantikan peranan kitab suci, masyarakat sekarang lebih cenderung memegang smartphone dibandingkan memegang kitab suci, karena di dalam smartphone telah ada aplikasi kitab suci itu sendiri.

Disadari atau tidak, manusia modern telah menjadikan media sebagai "agama baru". Baginya bisa saja agamanya tetap Islam. Namun tingkah laku sehari-hari telah dipengaruhi oleh media. Dan jika ada masalah dalam hidup yang menjadi tempat mengadu bisa jadi ialah media, bukan lagi agama yang dinyakini. Ketergantungan pada media inilah sama seperti orang beragama, mengalahkan agama, dan sadar atau tidak telah menjadikan media sebagai agama barunya.

\section{Kesimpulan}

Untuk menghadirkan sisi agama yang berfungsi integratif yang terpenting ialah sikap keberagamaan yang terbuka (inklusif) sangat berperan. Dan juga terpenting ialah Mengimplementasikan esensi nilai-nilai ajaran agama dalam kehidupan publik jauh lebih penting daripada sekedar terjebak pada simbol-simbol formal. Lebih jauh lagi, hubungan antar umat beragama yang menjadikan wajah agama sebagai integrasi masyarakat, diharapkan pada kerja sama yang nyata dalam kehidupan sehari-hari, semua agama beragenda sama untuk melawan musuh bersama, musuh dari kemanusiaan yaitu ketidakadilan sosial, kemiskinan, kebodohan, pelanggaran hak asasi manusia dan kepatuhan kepada tirani yang jauh dari kesadaran akan Ketuhanan Yang Maha Esa. Semua agama punya tanggung jawab terhadap kerja nyata ini supaya dapat terwujud secara maksimal.

Di sisi lain juga, fenomena masyarakat modern yang telah ketergantungan terhadap media termaksud juga televisi dan internet. Fenomena ini telah menunjukkan, bahwa manusia modern telah menjadikan media sebagai "agama baru". Ditunjukkan oleh tingkah laku sehari-hari yang telah 
dipengaruhi oleh media. Aktivitas sehari-hari mulai dari bangun tidur hingga tidur lagi, masyarakat modern, sebagian besarnya membutuhkan akses media melalui smartphone pribadi masing-masing dan tidak sedikit yang pertama diperhatikan saat bangun tidur ialah smartphone. Jika ada masalah dalam hidup yang menjadi tempat mengadu bisa jadi ialah media, bukan lagi agama yang dinyakini. Ketergantungan pada media inilah sama seperti orang beragama, mengalahkan agamanya sendiri, sehingga dengan sadar atau tidak telah menjadikan media sebagai agama barunya.

\section{Daftar Pustaka}

Adhiwardoyo, Sunaryo, Kerukunan Umat Beragama, Penghormatan Hukum, dan Perlindungan HAM, Jakarta: Dewan Pimpinan Pusat LDII, 2005

Agus Ahmad Safei, Nasib Toleransi Beragama di Era Bandung Juara, dalam Jurnal Kalam Volume 13 No 2 tahun 2016

Basyirudin Usman dan Asnawir, Media Pembelajaran,Jakarta: Ciputat Pers, 2002

Casanova, Jose, Public Religions in the Modern World, Chicago: The University of Chicago Press, 1994

Dwi Wahyuni, Nilai-Nilai Dasar Perjuangan HMI: Suatu Ikhtiar Mewujudkan Kerukunan Hidup Umat Beragama di Indonesia, dalam Jurnal Ilmu Agama, Volume 17 No 2 Desember 2016

Effendi, Bahtiar, Masyarakat Agama dan Pluralisme Keagamaan,Yogyakarta: Galang Printika, 2001

Geertz, Clifford, Religion of Java, Chicago: The University of Chicago Press, 1960

Ibrahim Idi Subandy, Kritik Budaya Komunikasi, Yogyakarta: Jalasutra, 2011

Kamus Besar Bahasa Indonesia, Jakarta: Balai Pustaka, 2001

Khairuni Nisa, Dampak Positif Negatif Sosial Media Terhadap Pendidikan Akhlak Anak (Studi Kasus di SMP Negeri 2 Kelas VIII Banda Aceh), dalam Jurnal Edukasi Volume 2 No 1 Januari 2016 Kurtz Lester R, Gods in the Global Village, Thousand Oaks: Pine Forge Press Lembaga Alkitab Indonesia, Alkitab, Jakarta: Lembaga Alkitab Indonesia, 2001

Mas'udi, Peranan Media Dalam Membentuk Sosio-Kultur Dan Agama Masyarakat (Menggagas Prinsip-Prinsip Etis Dalam Jurnalistik) dalam Jurnal At-Tabsyir Volume 1 No 2 Tahun 2013

Mulkhan, Abdul Munir, Ajaran dan Jalan Kematian Syekh Siti Jenar, Yogyakarta: Kreasi Wacana, 2002

M. Hatta, Agama dan Budaya Media dalam Jurnal Communicatus: Jurnal Ilmu Komunikasi, Volume 1 No 1 Tahun 2017

Nasution, Harun, Islam Ditinjau dari berbagai Aspeknya, Jakarta: UI-Press, 2011

Nottingham, Elizabeth K, Agama dan Masyarakat: Suatu Pengantar Sosiologi,Jakarta: Rajawali Press, 1993

Pardianto, Meneguhkan Dakwah Melalui New Media dalam Jurnal Komunikasi Islam Volume 03 No 01 Juni 2013

Primada Qurrota Ayun, Fenomena Remaja Menggunakan Media Sosial dalam Membentuk Identitas, dalam Jurnal Channel, Volume 3 No 2, Oktober 2015

Schumann, Olaf Herbert, Pendekatan Pada Ilmu Agama-Agama, Jakarta: BPK Gunung Mulia, 2013

Suara Merdeka, 27 Maret 2015, Indonesia Pasar Paling Menguntungkan. 